\title{
Observation Results of Lightning Performance in Distribution Lines
}

\author{
Teru Miyazaki Member (Tokyo Electric Power Company, miyazaki.teru@tepco.co.jp) \\ Shigemitsu Okabe Senior Member (Tokyo Electric Power Company, okabe.s@tepco.co.jp) \\ Kiyoshi Aiba Member (Tokyo Electric Power Company, aiba.kiyoshi@tepco.co.jp) \\ Takao Hirai Member (Tokyo Electric Power Company, hirai.t@tepco.co.jp)
}

Keywords: lightning stroke, distribution line, surge, lightning fault

Nearby trees and buildings affect frequency of direct lightning strokes to distribution lines because the lines can be located lower than nearby structures. It is necessary to grasp how lightning strikes distribution lines in the field based on observation data. The Tokyo Electric Power Company has conducted a field research to measure the waveforms of surge voltages and currents in order to provide effective preventive measures against distribution line faults due to lightning strokes. The observation has been carried out with still cameras and monitoring sensors of lightning surges. The authors have acquired data that include the characteristics of direct strokes to the lines, which are useful for improving the calculating the lightning faults rate of distribution lines.

About 80 percent of the faults (relay operation in substations) caused by lightning strokes within the observation zones was due to direct lightning strokes. The frequency of fault generation at the moment of direct lightning strokes was 49 percent; meanwhile there was only a 3 percent probability that the faults was due to indirect lightning strokes. A high percentage of the distribution line faults are presumably caused by direct lightning strokes based on the observation results.

The authors evaluated whether or not a flashover was generated in the observed direct strokes. Those analyses resulted in the frequency of flashover generation. Table 1 shows the results that the direct lightning was estimated to have caused flashover generation in 38 cases (78\%) among 49 cases. This value is relatively close to the calculated one by EMTP in this study.

Distribution line faults occur when following current continues after multiple phase flashovers. Table 2 shows the results of analysis
Table 1. Frequency of flashover generation

\begin{tabular}{|c|r|r|r|r|r|r|}
\hline \multirow{2}{*}{$\begin{array}{c}\text { No. of phases with } \\
\text { flashover }\end{array}$} & \multicolumn{3}{|c|}{ No. of observed flashovers (and rate) [\%] } \\
\cline { 2 - 6 } & $\begin{array}{c}\text { With } \\
\text { shieldiing }\end{array}$ & $\begin{array}{c}\text { Without } \\
\text { shielding wire }\end{array}$ & \multicolumn{2}{|c|}{ Total } \\
\hline Three phases & 14 & $(41 \%)$ & 12 & $(80 \%)$ & $\mathbf{2 6}$ & $\mathbf{( 5 3 \% )}$ \\
\hline Two phases & 5 & $(15 \%)$ & 1 & $(7 \%)$ & $\mathbf{6}$ & $(\mathbf{1 2 \%} \%$ \\
\hline Single phase & 5 & $(15 \%)$ & 1 & $(7 \%)$ & $\mathbf{6}$ & $(\mathbf{1 2 \%})$ \\
\hline Subtotal (with flashovers) & 24 & $(71 \%)$ & 14 & $(93 \%)$ & $\mathbf{3 8}$ & $\mathbf{( 7 8 \% )}$ \\
\hline No flashover & 10 & $(29 \%)$ & 1 & $(7 \%)$ & $\mathbf{1 1}$ & $\mathbf{( 2 2 \% )}$ \\
\hline Total & 34 & $(100 \%)$ & 15 & $(100 \%)$ & $\mathbf{4 9}$ & $(\mathbf{1 0 0 \%})$ \\
\hline
\end{tabular}

Table 2. Rate of continuation of following current

\begin{tabular}{|c|c|c|c|c|c|c|c|c|c|}
\hline \multirow[b]{2}{*}{$\begin{array}{c}\text { No. of phases } \\
\text { with } \\
\text { flashover }\end{array}$} & \multicolumn{3}{|c|}{$\begin{array}{c}\text { With shielding } \\
\text { wire }\end{array}$} & \multicolumn{3}{|c|}{$\begin{array}{c}\text { Without shielding } \\
\text { wire } \\
\end{array}$} & \multicolumn{3}{|c|}{ Total } \\
\hline & $\begin{array}{c}\text { No. of } \\
\text { flashover }\end{array}$ & $\begin{array}{r}\mathrm{N} \\
\text { foll } \\
\text { cu } \\
\text { (an }\end{array}$ & $\begin{array}{l}\text { of } \\
\text { wing } \\
\text { rent } \\
\text { rate) }\end{array}$ & $\begin{array}{c}\text { No. of } \\
\text { flashover }\end{array}$ & & $\begin{array}{l}\text { o. of } \\
\text { lowing } \\
\text { rrent } \\
\text { d rate) }\end{array}$ & $\begin{array}{c}\text { No. of } \\
\text { flashover }\end{array}$ & $\begin{array}{r}\mathrm{N} \\
\text { fol } \\
\mathrm{cu} \\
\text { (an }\end{array}$ & $\begin{array}{l}\text { of } \\
\text { wing } \\
\text { rent } \\
\text { rate) }\end{array}$ \\
\hline Three phases & 14 & 11 & $79 \%$ & 12 & 7 & $58 \%$ & 26 & 18 & $69 \%$ \\
\hline Two phases & 5 & 1 & $20 \%$ & 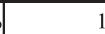 & 1 & $100 \%$ & 6 & 2 & $33 \%$ \\
\hline Single phase & 5 & 0 & $0 \%$ & 1 & 0 & $0 \%$ & 6 & 0 & $0 \%$ \\
\hline Total & 24 & 12 & $50 \%$ & 14 & 8 & $57 \%$ & 38 & 20 & $53 \%$ \\
\hline
\end{tabular}

to clarify the continuation of following current in 38 cases from which waveform data of power frequency voltages were obtained in the observation. The result indicates that following current also disappears even in the cases of flashovers at two and three phases. Taking all cases into account, the rate of continuation of following current is around 53 percent. These results provide new idea for improving the calculation of the distribution line faults rate. 


\title{
Observation Results of Lightning Performance in Distribution Lines
}

\author{
Teru Miyazaki* Member \\ Shigemitsu Okabe* Senior Member \\ Kiyoshi Aiba* Member \\ Takao Hirai* Member
}

\begin{abstract}
Nearby trees and buildings affect frequency of direct lightning strokes to distribution lines because the lines can be located lower than nearby structures. It is necessary to grasp lightning performance in distribution lines based on observation data. Lightning phenomena on actual distribution lines have been continuously observed for the last 10 years to rationalize lightning protection designs. The observation has been carried out with still cameras and monitoring sensors of lightning surges. The observation has clarified the frequency of direct lightning strokes to distribution lines, and the ratio of flashover probability. Those results can be useful to calculate the lightning faults rate of distribution lines.
\end{abstract}

Keywords: lightning stroke, distribution line, surge, lightning fault

\section{Introduction}

As distribution lines are extended and have lower insulation level than transmission equipment, lightning protection designs must consider not only direct lightning strokes but also indirect lightning strokes near distribution lines ${ }^{(1)}$. A recent study evaluated the ratio of flashovers in distribution lines by calculating the ratio of direct lightning strokes to distribution lines and that of induced voltages caused by indirect lightning strokes near distribution lines, using formulas for calculating lightning striking distances based on the electrogeometric models ${ }^{(2)(3)}$. Distribution lines, however, can be located lower than nearby trees and buildings, and these structures possibly affect lightning striking distances. It is necessary to recognize how lightning strikes distribution lines in fields in order to calculate the ratio of flashovers. Some electric power companies observe lightning strokes to distribution lines using still cameras that are triggered automatically ${ }^{(4)}$.

The Tokyo Electric Power Company (TEPCO) has conducted a field research to measure the waveforms of voltages and currents in order to provide effective preventive measures against distribution line faults due to lightning ${ }^{(5)}$. Thus, the authors have acquired data that include the characteristics of direct strokes to the actual distribution lines, which are useful for rationalizing lightning protection designs of distribution lines.

\section{Outline of Observations}

Observations of lightning strokes to the actual distribution lines have been conducted in the zones that experience many lightning strokes in Tochigi and Gunma Prefectures in the Kanto Plain, which are shown in Fig. 1. The area of each observation zone is 1.4 to $3.4 \mathrm{~km}^{2}$. A total of 100 cameras

\footnotetext{
* High Voltage \& Insulation Group R\&D Center, Engineering R\&D

Division, the Tokyo Electric Power Company

4-1, Egasaki-cho, Tsurumi-ku, Yokohama 230-8510
}

and 100 observation instruments operated in the zones from 1996 to 2001. During that period, the installation rates of the shielding wires and the arresters in the zones are approximately $80 \%$ and $39 \%$ respectively. The arresters include $\mathrm{ZnO}$ elements in the transformers in the zones. Then, 63 cameras and 125 instruments have been operating since 2002. The installation rates of the shielding wires and the arresters in the zones are approximately $96 \%$ and $54 \%$ since then. The height of medium-voltage distribution lines above ground is about $11.6 \mathrm{~m}$. Figure 2 shows the equipment installed on a pole.

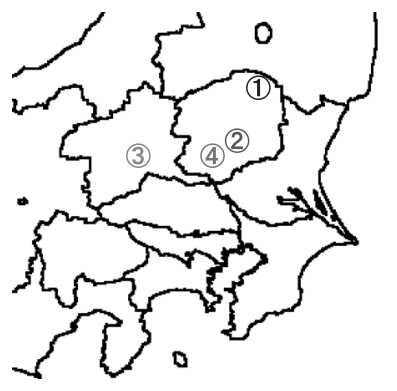

(a) (1) $\mathrm{K}$ zone (2) $\mathrm{U}$ zone (3) I zone (4) $\mathrm{T}$ zone (1996 2001)

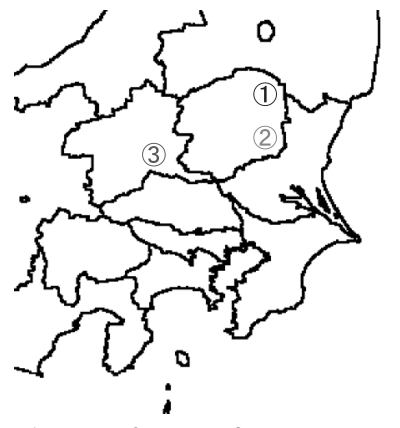

(b) (1) O zone (2) U zone (3) I zone (2002 )

Fig. 1. Observation zones 
2.1 Still Cameras for Observation The camera shutters are designed to operate automatically at the moment lightning is detected. Each shutter consists of a mechanical shutter and a liquid-crystal shutter. The mechanical shutter opens at the first lightning stroke, and then remains open, leaving all of the work to the liquid-crystal shutter. At $3 \mathrm{~ms}$ after detecting lightning, the liquid-crystal shutter opens fully and remains open for $250 \mathrm{~ms}$. The Cameras are installed in each zone. If two or more cameras photograph a lightning stroke simultaneously, the lightning striking location can be decided by an intersection point of directions of each camera.

\subsection{Instruments for Observing Surge Waveforms}

Two types of sensors have been used to observe lightning surge waveforms: a current-measuring sensor with a Rogowskii coil and a voltage-measuring sensor consisting of capacitive dividers and optical devices using pockels effect. Their measuring frequency bandwidth is $250 \mathrm{~Hz} \sim 250 \mathrm{kHz}$. Data are initially saved in the terminal of the observing instrument mounted on a concrete pole equipped with the sensors, and data are transferred to the database via a mobile telephone circuit at a specific time every day. This procedure saves labor in data collection.

The cameras and the surge waveform measuring instruments have GPS clocks in their time calibrators. That makes it possible to check the observed data using Lightning Position and Tracking System (LPATS) data ${ }^{(6)}$.

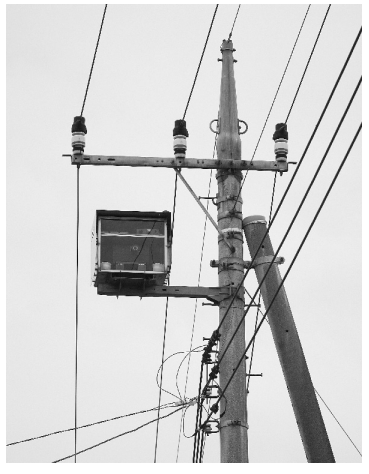

(a) Still camera

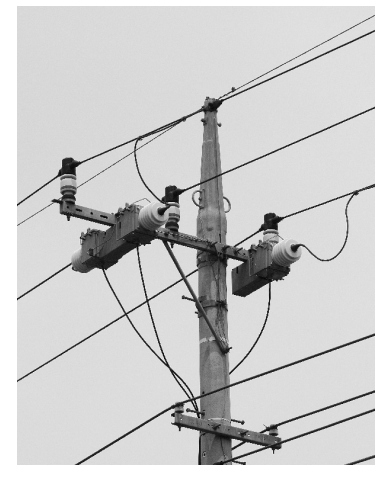

(b) Surge voltage sensor
Fig. 2. Pictures of apparatus for observation

\section{Results of Camera Observations}

The observations started in 1996, and changed zones in 2002. This paper covers the results obtained until 2005. Table 1 shows the frequency of the observed direct/indirect lightning strokes and the ratio of distribution line faults due to them. The zones in Table 1 are defined as the areas where striking locations can be decided by the cameras. Direct lightning strokes denotes a lightning stroke to distribution equipment including shielding wires, power lines and concrete poles. Indirect lightning strokes denote a lightning stroke other than direct lightning strokes within the zones. A fault represents an operation of any of relays in substations, whether or not reclosing in a substation is successful.

3.1 Frequency of Direct Lightning Strokes The number of the observed direct lightning strokes was 61 , which accounts for $22 \%$ of all the lightning strokes (278) during the period. The report ${ }^{(1)}$ calculated the frequency of direct lightning strokes to lines of $10 \mathrm{~m}$ above ground on a flat area with IKL (Iso-Keraunic Level) 30 as $0.34 / \mathrm{km} /$ year. The observation results of the actual lines confirmed the value $0.21 / \mathrm{km} /$ year as the same value in the case of excluding branch lines. The value of IKL is 28 to 36 in the observation zones, and the direct lightning frequency value $0.21 / \mathrm{km} / \mathrm{year}$ is lower than the $0.34 / \mathrm{km} /$ year in the reference 1 mentioned above. This is partly due to statistical dispersion and the following:

(1) Observations by nearby structures The frequency of direct lightning strokes can differ from the value calculated by assuming the site is flat in the reference 1 , because actual distribution lines are locally surrounded by objects such as trees and buildings.

(2) Differences in ground lightning stroke density In the calculation of the frequency of direct lightning strokes, the reference 1 assumes the number of lightning strokes to the ground to be $4 / \mathrm{km}^{2} /$ year and IKL value to be 30 . In the results of the present observations, from the area of the observation zones and the yearly number of lightning strokes, the number of lightning strokes to the ground can be calculated to be about $3.3 / \mathrm{km}^{2} /$ year, which is about 18 percent lower

Table 1. Frequency of observed direct/indirect lightning strokes and ratio of distribution line faults due to them

\begin{tabular}{|c|c|c|c|c|c|c|c|c|c|c|c|c|c|}
\hline year & $\begin{array}{c}\text { Total } \\
\text { length } \\
(\mathrm{km}) \\
<\mathrm{a}>\end{array}$ & $\begin{array}{c}\text { Area of } \\
\text { zones } \\
\left(\mathrm{km}^{2}\right) \\
<\mathrm{b}>\end{array}$ & $\begin{array}{c}\text { Total } \\
\text { lightning } \\
\text { strokes } \\
<\mathrm{c}>\end{array}$ & $\begin{array}{c}\text { Direct } \\
\text { lightning } \\
\text { strokes } \\
<\mathrm{d}>\end{array}$ & $\begin{array}{c}\text { Indirect } \\
\text { lightning } \\
\text { strokes } \\
<\mathrm{e}>\end{array}$ & $\begin{array}{c}\text { Frequency } \\
\text { of direct } \\
\text { stroke } \\
{[/ \mathrm{km} / \text { year }]} \\
\text { (d/a) }\end{array}$ & $\begin{array}{c}\text { Ground } \\
\text { lightning } \\
\text { density } \\
{\left[/ \mathrm{km}^{2} / \text { year }\right]} \\
\text { (c/b) }\end{array}$ & $\begin{array}{c}\text { No. of } \\
\text { faults } \\
\text { in } \\
\text { zones } \\
<\mathrm{f}>\end{array}$ & $\begin{array}{r}\text { Dire } \\
\text { strok } \\
\text { pa }\end{array}$ & $\begin{array}{l}\text { ct lightning } \\
\text { e faults }<\mathrm{g}> \\
(\mathrm{g} / \mathrm{f} \text { in } \\
\text { rentheses) }\end{array}$ & $\begin{array}{c}\text { Ratio of } \\
\text { direct } \\
\text { lightning } \\
\text { fault }(\mathrm{g} / \mathrm{d})\end{array}$ & $\begin{array}{c}\text { Indirect } \\
\text { lightning } \\
\text { stroke faults } \\
<\mathrm{h}>\text { (h/f in } \\
\text { parentheses) }\end{array}$ & $\begin{array}{l}\text { Ratio of } \\
\text { indirect } \\
\text { lightning } \\
\text { fault }(\mathrm{h} / \mathrm{e})\end{array}$ \\
\hline 96 & 13.4 & & 1 & 0 & 1 & 0.00 & 0.2 & 0 & 0 & & & ( & \\
\hline 97 & 27.3 & 9.3 & 24 & 1 & 23 & & 2.6 & 3 & 1 & $(33 \%)$ & $100 \%$ & $(67 \%)$ & 90 \\
\hline 98 & 34.0 & 11.3 & 17 & 2 & 15 & .06 & 1.5 & 2 & 1 & $(50 \%)$ & $50 \%$ & $1(50 \%)$ & $7 \%$ \\
\hline 99 & 34.0 & 11.3 & 36 & 8 & 28 & 24 & 3.2 & 6 & 5 & $(83 \%)$ & $63 \%$ & $1(17 \%)$ & $4 \%$ \\
\hline 00 & 34.0 & 11.3 & 82 & 23 & 59 & 0.68 & 7.3 & 10 & 10 & $(100 \%)$ & $43 \%$ & $(0 \%)$ & $0 \%$ \\
\hline 01 & 34.0 & 11.3 & 44 & 11 & 33 & 0.32 & 3.9 & 9 & 7 & $(78 \%)$ & $64 \%$ & $(22 \%)$ & $6 \%$ \\
\hline 02 & 26.8 & 6.5 & 21 & 7 & 14 & 0.26 & 3.2 & 3 & 3 & $(100 \%)$ & $43 \%$ & $(0 \%)$ & $0^{\circ}$ \\
\hline 03 & 26.8 & 6.5 & 6 & 1 & 5 & 0.04 & 0.9 & 0 & 0 & 1 & & 0 & \\
\hline 04 & 26.8 & 6.5 & 18 & 3 & 15 & 0.11 & 2.8 & 1 & 1 & $(100 \%)$ & $33 \%$ & $(0 \%)$ & $0 \%$ \\
\hline 05 & 26.8 & 6.5 & 29 & 5 & 24 & 0.19 & 4.5 & 2 & 2 & $(100 \%)$ & $40 \%$ & $0 \quad(0 \%)$ & $0 \%$ \\
\hline otal & 283.9 & 84.7 & 278 & 61 & 217 & 0.21 & 3.3 & 36 & 30 & $(83 \%)$ & $49 \%$ & $6(17 \%)$ & $3 \%$ \\
\hline
\end{tabular}


than the value in the reference 1 . It should be noted here that in camera observations, no photography is possible during camera dead times, which makes it necessary in a strict discussion of the correlation between the number of lightning strokes to the ground and the frequency of direct lightning strokes to include data from other observation systems such as LPATS.

3.2 Ratio of Distribution Line Faults The observation confirms that $83 \%$ of the distribution line faults were caused by direct lightning strokes (See Table 1). This fact suggests that direct lightning strokes are the major cause of present distribution faults. The percentage of direct and indirect lightning strokes that caused faults is shown in the direct/indirect lightning stroke fault columns in Table 1 . The ratio of faults due to the direct lightning strokes was 49 percent; meanwhile there was only a 3 percent that the faults were due to the indirect lightning strokes. These results suggest that a considerable degree of protective measures has been achieved for indirect lightning strokes due to lightning protection devices such as shielding wires and surge arresters. Moreover, those lightning protective measures are effective to some degree for direct lightning strokes that had been thought to inevitably damage distribution lines.

\section{Analysis of Observed Data due to Direct Light- ning Strokes to Distribution Lines}

A high percentage of the distribution line faults are presumably caused by direct lightning strokes based on the observation results. This chapter shows the analyses of direct lightning stroke patterns, and the flashover ratios due to the direct strokes are discussed. Whether waveforms were obtained by direct strokes or indirect strokes were estimated by the camera observations.

4.1 Lightning Points The points in distribution line facilities, which 61 direct lightning struck, were estimated by the photographs and classified into the five patterns shown in Fig. 3.

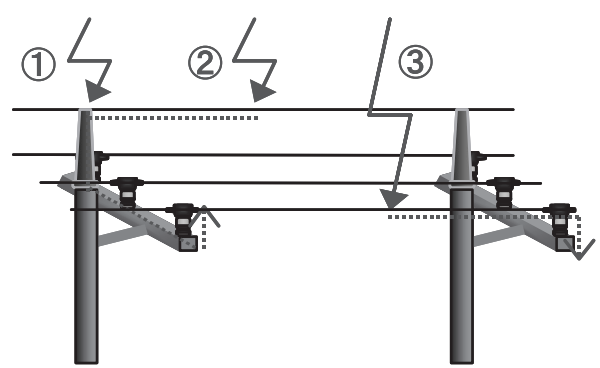

(a) With shielding wire

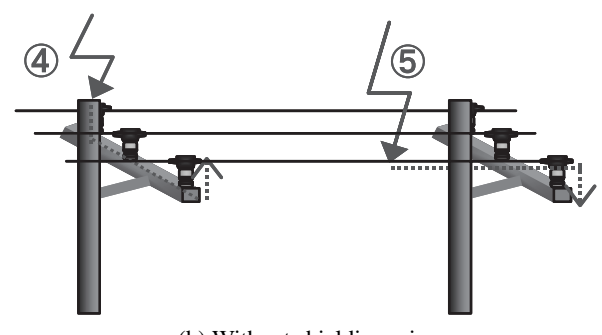

(b) Without shielding wire

Fig. 3. Clasisification of lightning strokes in terms of lightning points
Table 2 shows the observed lightning points and the ratio of the line faults in the case that shielding wires were installed and those were not installed. The direct lightning strokes to pole heads, whether or not shielding wires were installed, recorded the highest percentage. In Table 2(a), lightning stroked to power lines in the two cases where shielding wires were installed. In one of the two cases, the stroke to the power line may have caused by a side stroke from nearby trees based on the results of the camera observations, but the cause is not clear in the other case. The ratio of lightning strokes to power lines accounts for $5 \%$ even if shielding wires were not installed (See Table 2(b)). The report ${ }^{(7)}$ shows that lightning is likely to stroke naked wires compared with the case of insulated wires. Lightning striking distances of insulated wires can be one of the important issues when the effects of shielding wires are evaluated. Figure 4 shows an example of a direct lightning stroke to a pole head. The faults ratio of distribution lines without the shielding wires was $68 \%$. This value is 1.7 times as high as that of the lines with the shielding wires. This fact suggests that shielding wires are effective to suppress the ratio of distribution line faults in fields.

\subsection{Ratio of Flashover}

(1) Patterns of lightning surge voltage waveforms In the previous study, the authors showed the patterns of surge voltage waveforms due to direct strokes in the case that flashover of insulators occurs and does not occur ${ }^{(8)}$.

Figure 5(a) shows an example of an insulator voltage waveform without flashovers. The feature of this is that after the

Table 2. Lightning points and ratio of line faults

(a) With shielding wire

\begin{tabular}{|c|l|r|r|r|r|}
\hline Pattern & $\begin{array}{c}\text { Lightning } \\
\text { point }\end{array}$ & $\begin{array}{c}\text { No. of lightning } \\
\text { strokes }\end{array}$ & $\begin{array}{c}\text { No. of } \\
\text { faults }\end{array}$ & $\begin{array}{c}\text { Frequency } \\
\text { of faults }\end{array}$ \\
\hline \hline$(1)$ & Pole head & 25 & $(60 \%)$ & 11 & $44 \%$ \\
\hline$(2)$ & Ground wire & 12 & $(29 \%)$ & 6 & $50 \%$ \\
\hline$(3)$ & Power line & 2 & $(5 \%)$ & 0 & $0 \%$ \\
\hline & Others & 3 & $(7 \%)$ & 0 & $0 \%$ \\
\hline & Total & 42 & $(100 \%)$ & 17 & $40 \%$ \\
\hline
\end{tabular}

(b) Without shielding wire

\begin{tabular}{|c|l|r|r|r|r|}
\hline Pattern & $\begin{array}{c}\text { Lightning } \\
\text { point }\end{array}$ & $\begin{array}{c}\text { No. of lightning } \\
\text { strokes }\end{array}$ & $\begin{array}{c}\text { No. of } \\
\text { faults }\end{array}$ & $\begin{array}{c}\text { Frequency } \\
\text { of faults }\end{array}$ \\
\hline \hline$(4)$ & Pole head & 18 & $(95 \%)$ & 13 & $72 \%$ \\
\hline 5 & Power line & 1 & $(5 \%)$ & 0 & $0 \%$ \\
\hline & Others & 0 & $(0 \%)$ & 0 & $0 \%$ \\
\hline & \multicolumn{7}{|c}{ Total } & 19 & $(100 \%)$ & 13 & $68 \%$ \\
\hline
\end{tabular}

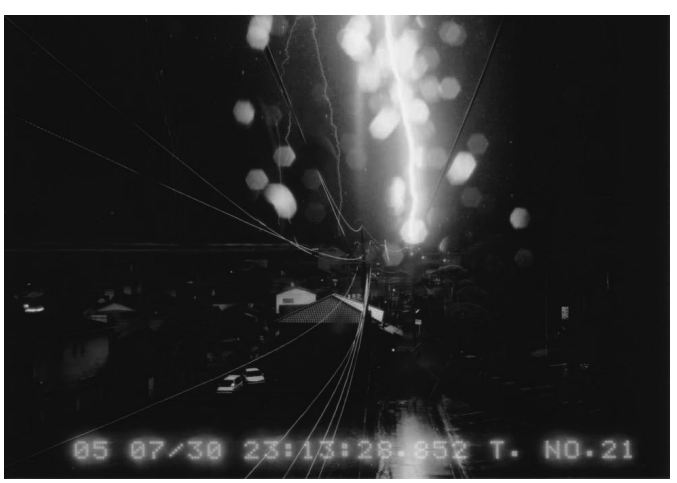

Fig. 4. Example of direct lightning stroke to pole head 


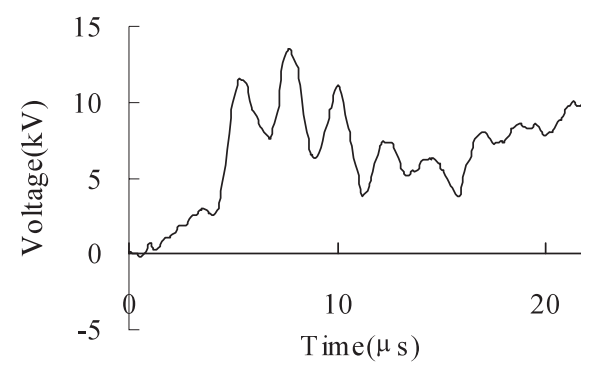

(a) In the case of no flashover

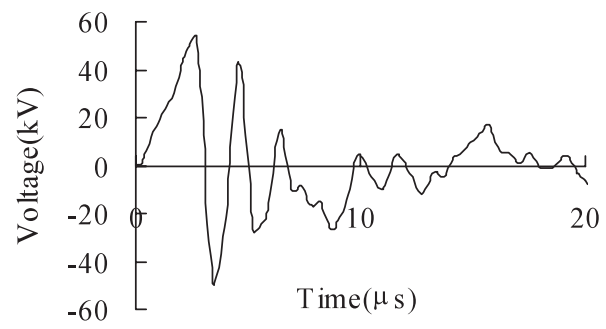

(b) In the case of flashover

Fig. 5. Examples of insulator voltage waveforms

Table 3. Ratio of flashover generation in the case that shielding wires were installed and were not installed

\begin{tabular}{|c|r|r|r|r|r|r|}
\hline \multirow{2}{*}{$\begin{array}{c}\text { No. of phases with } \\
\text { flashover }\end{array}$} & \multicolumn{5}{|c|}{ No. of flashovers (ratio) } \\
\cline { 2 - 6 } & $\begin{array}{c}\text { With } \\
\text { shieldiing wire }\end{array}$ & $\begin{array}{c}\text { Without } \\
\text { shielding wire }\end{array}$ & \multicolumn{2}{|c|}{ Total } \\
\hline Three phases & 14 & $(41 \%)$ & 12 & $(80 \%)$ & $\mathbf{2 6}$ & $\mathbf{( 5 3 \% )}$ \\
\hline Two phases & 5 & $(15 \%)$ & 1 & $(7 \%)$ & 6 & $(\mathbf{1 2 \%})$ \\
\hline Single phase & 5 & $(15 \%)$ & 1 & $(7 \%)$ & $\mathbf{6}$ & $\mathbf{( 1 2 \%})$ \\
\hline Subtotal (with flashovers) & 24 & $(71 \%)$ & 14 & $(93 \%)$ & $\mathbf{3 8}$ & $\mathbf{( 7 8 \% )}$ \\
\hline No flashover & 10 & $(29 \%)$ & 1 & $(7 \%)$ & $\mathbf{1 1}$ & $\mathbf{( 2 2 \%})$ \\
\hline Total & 34 & $(100 \%)$ & 15 & $(100 \%)$ & $\mathbf{4 9}$ & $(\mathbf{1 0 0 \%})$ \\
\hline
\end{tabular}

first peak, voltage decreases gradually with the oscillations, probably due to reflection of surge waves. In Fig. 5(b), an example of a waveform with a flashover shows a reversal of polarity in the wave front part at the moment of the flashover.

(2) Ratio of flashover generation in fields The authors evaluated whether or not a flashover was generated in the observed direct strokes at the moment of lightning on the basis of the features of the insulator voltage waveforms mentioned above. Those analyses resulted in the ratio of flashover generation. Table 3 shows the results that the direct lightning was estimated to have caused flashover generation in 38 cases (78\%) among 49 cases. Moreover, 3-phase flashovers were found in 26 cases $(53 \%)$ among the 49 cases mentioned above. Both 2-phase and 1-phase flashovers were found in 6 cases $(12 \%)$. Those results suggest that about 20 percent of the total direct lightning strokes did not cause flashovers though direct lightning strokes had been thought to inevitably cause flashover generations because of their low insulation level. Table 3 also shows the ratios of flashovers in the case that the shielding wires were installed and were not installed. The total ratio of the flashovers with the shielding wires is $71 \%$, which is lower than the ratio of $93 \%$ without shielding wires.

\subsection{Ratio of Continuation of Following Current}

Distribution line faults occur when following current continues after multiple phase flashovers.

Whether or not a following current continued after flashovers at insulators was estimated by one cycle of power
Table 4. Ratio of continuation of following current in the case that shielding wires were installed and were not installed

\begin{tabular}{|c|c|c|c|c|c|c|c|c|c|}
\hline \multirow{3}{*}{$\begin{array}{c}\begin{array}{c}\text { No. of phases } \\
\text { with } \\
\text { flashover }\end{array} \\
\text { Three phases }\end{array}$} & \multicolumn{3}{|c|}{$\begin{array}{c}\text { With } \\
\text { shielding wire } \\
\end{array}$} & \multicolumn{3}{|c|}{$\begin{array}{c}\text { Without } \\
\text { shielding wire }\end{array}$} & \multicolumn{3}{|c|}{ Total } \\
\hline & \multirow{2}{*}{\begin{tabular}{|r|}
$\begin{array}{c}\text { No. of } \\
\text { flashover }\end{array}$ \\
14 \\
\end{tabular}} & \multicolumn{2}{|c|}{$\begin{array}{c}\begin{array}{c}\text { No. of } \\
\text { following } \\
\text { current } \\
\text { (ratio) }\end{array} \\
\end{array}$} & \multirow{2}{*}{\begin{tabular}{|r|}
$\begin{array}{c}\text { No. of } \\
\text { flashover }\end{array}$ \\
12 \\
\end{tabular}} & \multicolumn{2}{|c|}{$\begin{array}{c}\begin{array}{c}\text { No. of } \\
\text { following } \\
\text { current } \\
\text { ( ratio) }\end{array} \\
\end{array}$} & \multirow{2}{*}{\begin{tabular}{|r|}
$\begin{array}{c}\text { No. of } \\
\text { flashover }\end{array}$ \\
26 \\
\end{tabular}} & \multicolumn{2}{|c|}{$\begin{array}{c}\text { No. of } \\
\text { following } \\
\text { current } \\
\text { (ratio) }\end{array}$} \\
\hline & & 11 & $79 \%$ & & 7 & $58 \%$ & & 18 & $69 \%$ \\
\hline Two phases & 5 & 1 & $20 \%$ & & 1 & $100 \%$ & 6 & 2 & $33 \%$ \\
\hline Single phase & 5 & 0 & $0 \%$ & & 0 & $0 \%$ & 6 & 0 & $0 \%$ \\
\hline Total & 24 & 12 & $50 \%$ & 14 & 8 & $57 \%$ & 38 & 20 & $53 \%$ \\
\hline
\end{tabular}

frequency voltage waveforms measured up to $20 \mathrm{~ms}$. Table 4 shows the results of the analysis to clarify the continuation of following current in 38 cases from which waveform data of power frequency voltages were obtained. General distribution systems in Japan are of isolated neutral systems, and if flashover of insulators occurs only at one phase, the following current will naturally disappear because of a small ground-fault current. Table 4 indicates that following current also disappears even in the cases of flashovers at two and three phases. Taking all cases into account, the ratio of the continuation of following current is a total of 53 percent. These results provide new idea for improving the calculation of the distribution line faults rate because multiple flashovers are regarded as the line faults under present calculations. The continuation ratio in the case the shielding wires were installed is $50 \%$. This value is lower than the ratio of $57 \%$ in the case shielding wires were not installed, however the ratio with the shielding wires is higher than that without shielding wires in the case of three phases flashovers. This phenomena is not clear, but short circuit capacity or phase angles of power frequency voltages can affect the continuation ratio of following currents in these cases. The authors will conduct more detailed validations of the observed data.

\section{Estimation of Flashover Ratio with EMTP}

The ratio of flashover in the case of direct lightning strokes was calculated by EMTP to verify the observed result (78\%).

(1) Conditions for calculations The distribution line was simulated by 5 -phase distribution constants consisting of the 1-phase of a shielding wire and 4-phase of power lines (3phase medium-voltage lines and 1-phase low-voltage line). A grounding system model was used in the calculations ${ }^{(9)}$ (See Fig. 6). The model simulates the reduction of ground resistance due to soil ionization and sparkover (hereafter called Pole S.O.) between a grounding lead conductor and a concrete pole with a switch. The other analytical conditions are shown in Table 5. These values are determined by the data of the observation zones.

Under the conditions, two types of flashover voltage were set, as $120 \mathrm{kV}$ ( $=50 \%$ FOV of the insulator) and $150 \mathrm{kV}(=$ $100 \%$ FOV of the insulator), and two types of a distance (hereafter called D) between a grounding electrode and a pole underground were also set, as $5 \mathrm{~cm}$ and $50 \mathrm{~cm}$. Then, the minimum lightning currents that causes flashover was calculated and ratios of flashover generation were estimated using a cumulative frequency distribution of lightning current ${ }^{(10)}$.

(2) Results of calculations Figure 7 shows the 


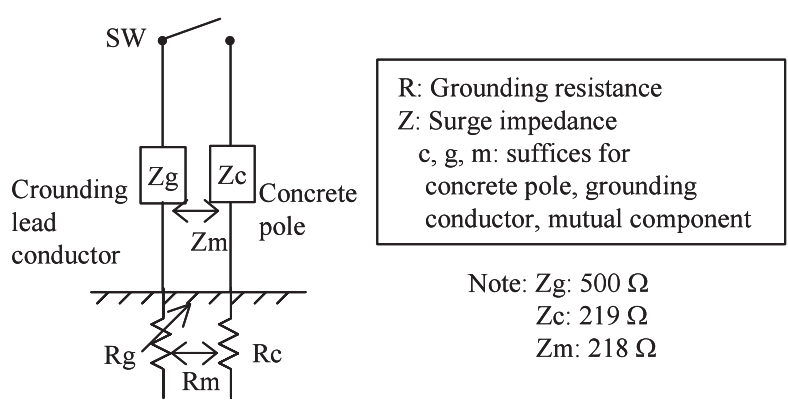

Fig. 6. Model of concrete pole and grounding electrode

Table 5. Conditions for analysis

\begin{tabular}{|l|l|}
\hline Line model & Disbributed-parameter line \\
\hline Calculation frequency & $100 \mathrm{kHz}$ \\
\hline No. of poles, span & 11 poles, 36m (Line ends: Matching) \\
\hline Installation rate of grounding & $50 \%$ (1 electrode / 2 poles) \\
\hline $\begin{array}{l}\text { Break down voltage between } \\
\text { concrete pole and grounding } \\
\text { lead conductor }\end{array}$ & $60 \mathrm{kV}$ \\
\hline Stady-state grounding resistance $(\mathrm{Rg})$ & $30 \Omega, 50 \Omega, 70 \Omega, 90 \Omega$ \\
\hline Lightning current waveform & $2 / 70 \mu \mathrm{sec}$, Ramp wave \\
\hline Lightning point & Ground wire (Middle part of the line) \\
\hline Lightning path impedance & $400 \Omega$ \\
\hline
\end{tabular}

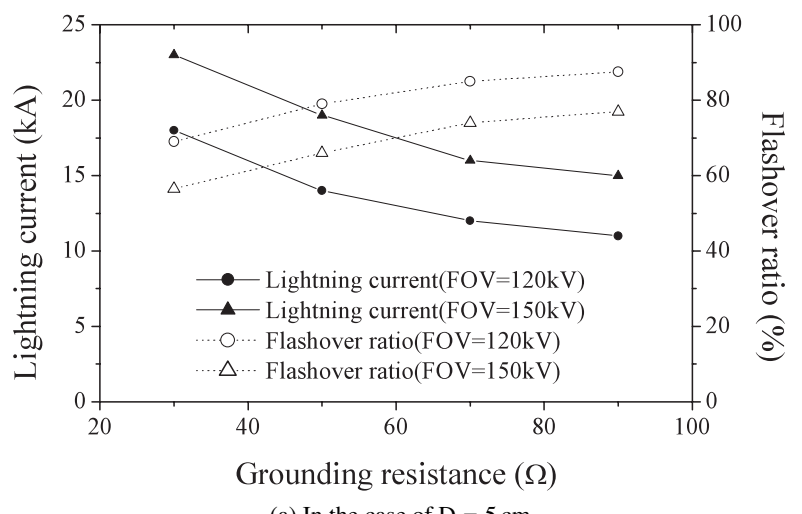

(a) In the case of $\mathrm{D}=5 \mathrm{~cm}$

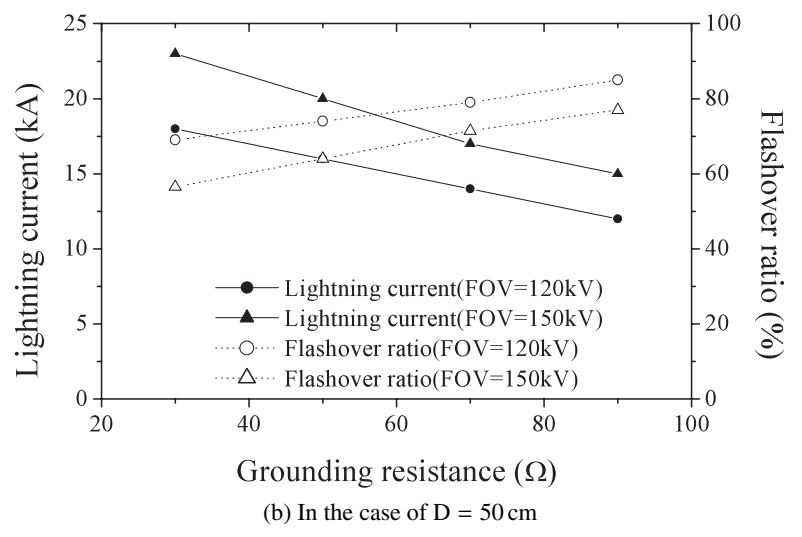

Fig. 7. Calculated flashover ratio by EMTP

results of the calculations. Figure 7(a) was calculated under the condition of $D=5 \mathrm{~cm}$, Figure 7(b) was under the condition of $\mathrm{D}=50 \mathrm{~cm}$. The average grounding resistance $(\mathrm{Rg})$ of the observation zones is about $50 \Omega$. The ratio of flashover was calculated to be $79 \%$ under the condition that FOV is $120 \mathrm{kV}$ and $\mathrm{Rg}$ is $50 \Omega$ in Fig. 7(a). This value $79 \%$ is close to the value $78 \%$ estimated by the result of the observations. The flashover ratios in Fig. 7(b) were lower than those in Fig. 7(a). The decrease in the flashover ratios is attributed to the decrease of mutual resistance $(\mathrm{Rm})$ between a grounding electrode and a concrete pole. This fact shows the effect of Pole S.O. can be obtained when Rm is small.

\section{Conclusions}

This paper describes analyses of observations of lightning strokes to actual distribution lines from 1996 to 2005. The report can be summarized as follows:

(1) The camera observation of lightning strokes to distribution lines in the field over a period of ten years showed a total of 278 lightning strokes in the observation area, and 61 data of direct lightning strokes to distribution lines were obtained.

(2) The frequency of direct lightning strokes to distribution lines estimated was $0.21 / \mathrm{km} / \mathrm{year}$, and the ground lightning density was $3.3 / \mathrm{km}^{2} /$ year.

(3) The faults ratio of the distribution lines without shielding wires was 68 percent of 19 direct lightning strokes. This value is 1.7 times as high as that of the lines with the shielding wires. The ratio of lightning strokes to power lines accounts for $5 \%$ of 19 direct strokes even if shielding wires were not installed.

(4) About 80 percent of the 36 faults (relay operation in substations) caused by lightning strokes was due to the direct lightning strokes. The ratio of fault was about 50 percent of 61 direct lightning strokes.

(5) An analysis was carried out about how often the insulator flashovers were caused by direct lightning strokes. The ratio of flashover generation is estimated to be about 80 percent of 49 direct lightning strokes. This value is relatively close to the calculated one by EMTP in this paper.

(6) The ratio of continuation of following current was estimated to be around 50 percent of 38 direct lightning strokes. The results provide new idea for improving the calculation of the distribution line faults rate.

(Manuscript received March 26, 2007, revised Aug. 8, 2007)

\section{References}

(1) Sectional Committee for Distribution Lines, Lightning Protection Design Standard Study Committee: "Lightning Protection Design Standard for Distribution Lines", Technical Report in CRIEPI, No.13, Vol.4 (1963)

( 2 ) IEEE WG: "A simplified method for estimating lightning performance of transmission lines", IEEE84, SM698-7 (1984)

( 3 ) A. Asakawa, S. Yokoyama, and Y. Hashimoto: "Development of the Analytical Method for the Outage Ratio Due to Lightning on Power Distribution Lines (Part 1)“, Technical Report in CRIEPI, No.T92087 (1993)

( 4 ) H. Taniguti, H. Sugimoto, and S. Yokoyama: "Observation of Lightning Performance on Power Distribution Line by Still Cameras", T. IEE Japan, Vol.116-B, No. $\bigcirc$, pp.1138-1143 (1996)

( 5 ) T. Miyazaki, S. Okabe, K. Aiba, and T. Hirai: "Statistical Analysis of Lightning Surges on Distribution Lines Based of the Observation", IEEJ Trans. PE, Vol.126, No.1, pp.97-104 (2006-1)

( 6 ) T. Shioda, T. Narita, E. Zaima, and M. Ishii: "Performance Evaluation of LPATS-T at TEPCO", 25th International Conference on Lightning Protection, No.2.1 (2000)

( 7 ) Y. Hashimoto, S. Yokoyama, T. Yokota, and A. Asakawa: "Studies on Characteristics of Lightning Stroke Distance to Power Distribution LinesDischarge Characteristics of Open Wire and Insulated Wire-_, T. IEE Japan, Vol.115-B, No.12, pp.1508-1514 (1996-12)

( 8 ) T. Hirai, T. Takinami, and S. Okabe: "Observation of Lightning Phenomena on Real Distribution Lines", The Papers of Joint Technical Meeting on electrical Discharges, Switching and Protecting Engineering and High Voltage, 
IEE Japan, HV-01-94 (2001)

( 9 ) T. Miyazaki, S. Okabe, K. Mori, K. Aiba, T. Hirai, J. Yoshinaga, and S. Sekioka: "A Study on a Lightning-Surge Analysis Composite Model of a Reinforced Concrete Pole and a Grounding Electrode in Power Distribution Lines", IEEJ Trans. PE, Vol.126, No.7, pp.669-678 (2006-7)

(10) Subcommittee for Power Stations and Substations, Lightning Protection Design Committee: "Guide to Lightning Protection Design for Power Stations, Substations and Underground Transmission Lines", Technical Report of CRIEPI, No.T40 (1995)

Teru Miyazaki (Member) received B.Eng. and M.Eng. Degree

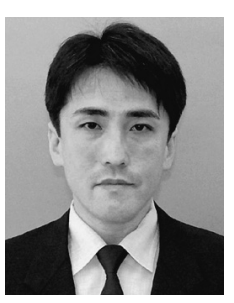
in electrical engineering from the University of Electoro-Communications in 1995 and 1997 respectively. He joined the Tokyo Electric Power Company in 1997 and at present a member of High Voltage \& Insulation Group at R \& D center in the Tokyo Electric Power Company. His main research interest is the lightning protection design of a power distribution line. He is a member of IEEE.

Shigemitsu Okabe (Senior Member) received B.Eng.,M.Eng. and Dr.

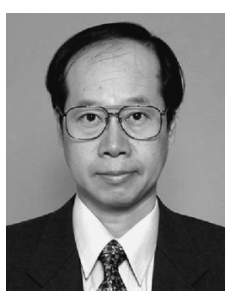
Degree in electrical engineering from the University of Tokyo in 1981, 1983 and 1986, respectively. He joined the Tokyo Electric Power Company in 1986 and at present a group manager of High Voltage \& Insulation Group at R \& D center in the Tokyo Electric Power Company. He was a visiting scientist at Technical University Munich in 1992. He has been involved in several research projects on the electrical insulation of transmission and distribution apparatuses. He is a member of IEEE.
Kiyoshi Aiba (Member) received B.Eng. and M.Eng. Degree in elec-

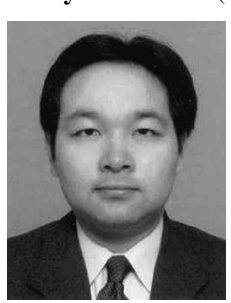
trical engineering from Keio University in 1991 and 1993 respectively. He joined the Tokyo Electric Power Company in 1993 and at present a member of High Voltage \& Insulation Group at R \& D center in the Tokyo Electric Power Company. His main research interest is the lightning protection design of a power distribution line.

Takao Hirai (Member) received B.Eng. in electrical engineering from

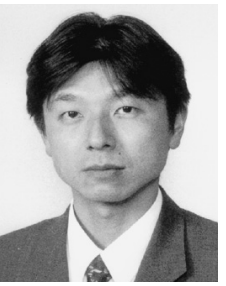
Waseda University in 1991. He joined the Tokyo Electric Power Company in 1991 and at present a group manager of technology and service group at Turumi Branch in the Tokyo Electric Power Company. He studied lightning protection design of a power distribution line when he worked for the R \& D center. 